\title{
Ki-67 Positive Cells Greater than 20
} Percent

National Cancer Institute

\section{Source}

National Cancer Institute. Ki-67 Positive Cells Greater than 20 Percent. NCI Thesaurus.

Code C161841.

A semi-quantitative microscopic finding indicating that more than 20 percent of the cells in sample are detected following staining using an anti-Ki-67 antibody. 